\title{
A TECHNO-FINANCIAL ANALYSIS OF TILAPIA PRODUCTION IN THE RECIRCULATING AQUACULTURE SYSTEMS
}

\author{
Samir Ahmad Ali*
}

\section{ABSTRACT}

The extensive fish farming in Egypt is mainly dependent on drainage water of agriculture, where pollution is most probably occurs. By law the Ministry of Public Affairs does permit raising fish on fresh water. Moreover, extensive fish farming in Egypt means tremendous losses in both land and water. To produce one $\mathrm{kg}$ of fish needs around $2 \mathrm{~m}^{2}$ of land and $5 \mathrm{~m}^{3}$ of water. The most feasible solution to overcome such problems is to develop a semi-intensive fish farming.

A techno financial analysis of tilapia production was conducted using a recirculating aquaculture system facility, situated at the Banha University, Agriculture College. Tilapia (1.0g), were stocked in the tanks; temperature and water quality parameters were carefully managed until the fish reached the harvestable size (500g) after 180days. The survival rate and feed conversion ratio (FCR) were $90 \%$ and 1.5 respectively.

The results showed that, the operational cost involving the system production was suited and economically viable.

Breakeven price above variable cost, breakeven price above fixed cost and breakeven yield estimated were L.E. 7.96, L.E. 9.33and 155,495kg respectively. The sensitivity analysis revealed that, increasing in the fixed cost by $+10 \%$ decreased the internal return rate (IRR) from $34 \%$ to $23 \%$. Also, decreasing the revenue by $-10 \%$ decreased internal return rate (IRR) from 34\% to $22 \%$. While, change both increasing in the fixed cost by $+10 \%$ and decreasing the revenue by $-10 \%$ at the same time decreased internal return rate (IRR) from $34 \%$ to $11 \%$.

Key words: Tilapia, recirculating system, Aquaculture, sensitivity analysis, breakeven yield, breakeven cost, economic analysis.

\footnotetext{
*Agric. Eng. Dept., Fac. Agric., Moshtohor, Toukh, Qalubia, P.O. Box, 13736,

Egypt. Phone: +2 0132467034 Fax: +2 013246778

E-Mail samir.ali@fagr.bu.edu.eg
} 


\subsection{INTRODUCTION}

quaculture is one of the fastest growing sectors of food
production in the world. Cultured species such as tilapia,
catfish, salmon, trout, oysters and clams are high in demand and the profit level is very high. The boom in this industry can be attributed to the growing demand for a healthy, tasty and affordable food as well as the sharp decline in wild fish populations as a result of overharvest and water pollution (Helfrich \& Libey, 1990). The rampant pollution of fresh water resources has also necessitated the need for the culturing of fish in waters free from contamination. Recirculating aquaculture system (RAS) technology has been found to provide away in solving this problem. This is a technology designed for holding and growing a wide variety of aquatic species and defined as production units which recycle water by passing it through filters to remove metabolic and other waste products (Kazmierczak \& Caffey, 1995).

In 2008, commercial aquaculture production was about 2.8 million tonnes with a corresponding estimated value of $\$ 3.7$ billion. The production was forecasted to reach 3.7 million tonnes by the end of 2010 (FAO, 2009; FAO GLOBEFISH, 2011a). By 2015, world production is expected to reach between 4.6 million tonnes and 5 million tonnes (FAO, 2010).

The systems can be designed to cater for different capacities and efficiencies. In comparison to the traditional aquaculture practices, RAS offers more independence from the external environment (i.e. increased levels of control) which provides a basis for improved risk management (Rawlinson, 2002). Majority of the worlds tilapia productions are done using the pond systems, however, in the temperate regions, RAS is employed in the production due to the cold climatic conditions. This makes the production cost higher since huge capital is expended on the RAS construction and the running of other production mechanisms such as heating, pumping and filtering of the water (Alceste \& Jory, 2002). A lot of countries are now using RAS in fish production; however, production level is very low compared to other forms of fish culture (Martins et al., 2010). The construction and operation of these facilities require high capital injection and this sometimes serves as disincentive to 
prospective investors (Schneider etal., 2006). To make up for this, high stocking densities are required in the productions to be able to cover the investment costs and generate profit. However, the need for high stocking densities also comes with some welfare challenges (Martins et al., 2005). Aquaculture production using RAS has been the focus of research and developmental efforts of many groups for decades.

Recirculation aquaculture systems (RAS) are new and a unique way to culture fish. In place of the old conventional methods of growing fish, RAS offers a means to rear fish in indoor tanks where the environment can be controlled. The system filters and cleans the water for recycling back through fish culture tanks (Helfrich\&Libey, 1990). In RAS, more than $90 \%$ of the water is re circulated through a series of biological and mechanical filtration systems so that only a fraction of the water is consumed (Rawlinson \& Foster, 2000). "New" water is added to the tanks only to make up for losses through splash outs; evaporation and for those that is used to flush out waste materials. Fish cultured using this technology must be provided with a congenial environment and conditions suitable for growth and to remain healthy. Clean water, dissolved oxygen, and optimal temperatures are required to ensure better growth. These are achieved by the filtration system, aerators and heaters incorporated in the technology design. The filtration system purifies the water and removes or detoxifies products harmful to the culturing media and species. Organic particles from faeces and uneaten feed are removed by the mechanical particle filters, whereas the poisonous metabolic waste products TAN and NO2 (total ammonium nitrogen and nitrite) are oxidized to less toxic compounds (NO3) in nitrification filters. These filters are sometimes referred to as aerobic biofilters or nitrification filters. In the construction of the RAS facility, proper sizing of all system components is very important. When the RAS plant is oversized for its application, the system would function but the cost of running the facility would be high. Undersized RAS, on the other hand, would not be able to maintain proper environment to sustain fish production.

RAS offer various advantages ranging from reduction water consumption (Verdegem et al., 2006 in Martins et al., 2010), to the provision of improved opportunities for waste management and nutrient recycling 
(Piedrahita, 2003 in Martins et al., 2010). The systems environment can be controlled to achieve better hygiene and disease management (e.g. summer felt et al., 2009 in Martins et al., 2010). It offers a near complete environmental control to maximize fish growth year-round, and the flexibility to locate production facilities near large markets(Masser et al., 1999; Schneider et al., 2010) to deliver a fresher, safer product and lower transport cost (Timmons et al., 2001). In terms of product security RAS offers a high degree of product traceability (Smith, 1996; Jahncke\& Schwarz, 2000) and biological pollution control (no escapees, Zohar et al., 2005 in Martins, et al., 2010).

They may be used as grow-out systems to produce food fish or as hatcheries to produce eggs and fingerling, for stocking and ornamental fish for home aquariums (Helfrich \& Libey 1990).

The objectives of this study were estimate the operational cost involved and from this, estimate the breakeven cost, (1) identify and describe the constraints unique to the recirculating aquaculture systems (RAS), (2) to perform financial feasibility of a scale-up production, and (3) to conduct sensitivity analysis to highlight their effect on profitability

\section{Analysis Procedures.}

\subsection{System description:}

There is no single recommended design for growing fish in an RAS. In general, a system includes tanks to culture fish, pumps to maintain water flow, and some form of water treatment to maintain water quality. Following are a few considerations on system design and how design can affect profitability. For a more complete explanation of component options and management issues, see Ali, 2006.

The data used for this publication are taken from experiences at ElNenaiea Fish Farm (Ali, et al., 2006) and Banha University, Faculty of Agriculture, Fish Farm Project.

The system consists of a quarantine tank, two nursery tank, and eight grow out tanks. The system represented in this example consists of eleven tanks: one 6.0 cubic meter quarantine tank $(\mathrm{Q})$; two 15.0 cubic meter nursery tanks ( $\mathrm{N} 1$ and $\mathrm{N} 2$ ), and eight100.0 cubic meter grow-out tanks. The quarantine and nursery tanks have their own water filtration systems, while each set of four grow out tanks shares a water treatment system. 
Fish are initially stocked in the Q tank, grown and screened for diseases for 30 days, then harvested, divided into equal numbers, and restocked into the two $\mathrm{N}$ tanks. After 30 days of growth, the fish are transferred from one $\mathrm{N}$ tank into one of the eight $\mathrm{G}$ tanks, where they are grown an additional 120 days until harvest. This 120-day period is divided into four distinct production stages of 30 days each (defined as GS1, GS2, GS3, and GS4 in figure 1). Each of these stages has a different feed rate, oxygen demand, and water flow requirement. (An alternative to this configuration would be to move the fish into a different tank for each of the 30-day periods.) It is important to note that the model reflects four stages of growth in the grow out tank phase, so that changing production costs can be accommodated within the spreadsheet. This should not be confused with the need to have a total of eight grow out tanks in order to meet required production volumes for cash flow. Additionally, your total number of days to harvest may differ with species, culture temperature, and final average harvest size.

Once system is fully stocked, one of the eight $G$ tanks is harvested for sale every 30 days. The system has a maximum culture density of 83.55 $\mathrm{kg} \mathrm{m}{ }^{-3}$ of water in each grow out tank, and each harvest yields approximately $8355 \mathrm{~kg}$ of fish. Depending on design specifications, the maximum culture density may be different. The author of this publication designs systems not to exceed a maximum culture density of approximately $80-85 \mathrm{~kg} \mathrm{~m}^{-3}$ of water. With 12 harvests annually (one every 30 days once the facility is fully stocked), total production for the facility is approximately $200,000 \mathrm{~kg}$ per year.

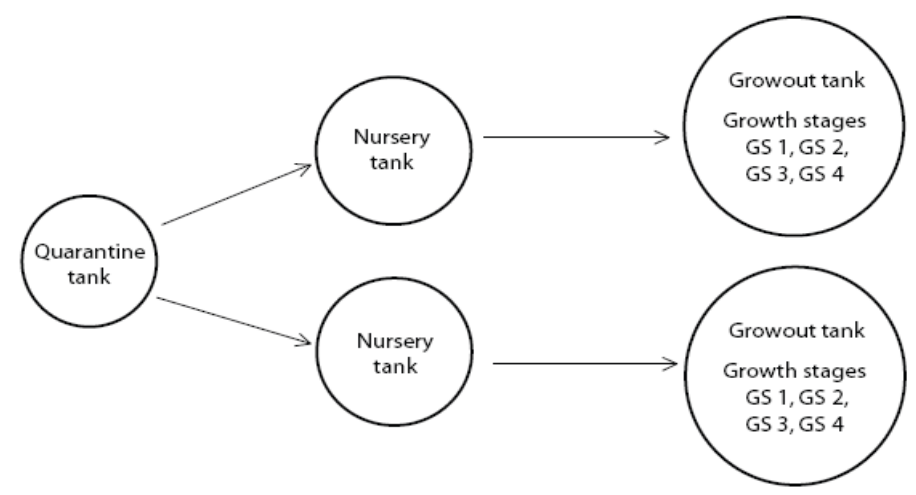

Figure 1. Diagram of fish flow through system. 


\subsection{Production model for estimations}

\subsubsection{Biological Model}

These tools were used to estimate incomes and production; growth and mortality. The simplest tool to use is the formulas for biomass, $B_{t}$, and biomass value, $V_{t}$ :

$$
B_{t}=N_{t} \times W_{t}
$$

Where, $N_{t}$ is the number of fish at time $t$, and $W_{t}$ is the weight of the fish at time $t$. The sales output (value of the fish) from the production is calculated by multiplying price with quantity:

$$
V_{t}=P_{w} \times B_{t}
$$

Where $V_{t}$ is the biomass value and $P_{w}$ is the price pr. $\mathrm{kg}$ of fish. The $\mathrm{kg}$ price is assumed to increase as the weight of the fish increases $P_{w}>0$ ). This formula does not take into consideration the effect of seasonal variations on the price of fish (Bjørndal 1987).

Feed Conversion Ratio (FCR): is considered an important biological production parameter to consider, and could be calculated from the following equation (Einen\&Roem, 1997):

$$
F C R=\frac{F B}{B M_{2}-B M_{1}-F T}
$$

Where FCR is $\mathrm{kg}$ consumed feed per $\mathrm{kg}$ growth, $F B$ consumed feed in $\mathrm{kg}, \mathrm{BM}_{2}$ is biomass at harvest, $\mathrm{BM}_{1}$ is start biomass, or biomass at stocking, and FT is fish lost to mortality.

\subsubsection{Financial Analysis.}

\subsubsection{Net income.}

The net income of the production can be estimated using the following formula:

$$
\text { Net income }=\text { Total revenue }- \text { Total production cost }
$$

Variable costs are those directly related to production; energy, bicarbonate, fingerlings, chemicals, maintenance and labor. According to Hoff, (1998), Variable unit costs, represent the cost involved to produce a $\mathrm{kg}$ of the produce and it's given by the formula:

$$
\text { Variable unit }(\mathrm{kg}) \text { cost }=\frac{\text { Total Variable costs }}{\text { Harvested Biomass }}
$$


Marginal Contribution:

The marginal contribution is the amount of money needed to cover the fixed costs and an eventual profit.

Marginal Contribution

$$
=\text { Operational income }- \text { Variable costs }
$$

The marginal contribution per unit represents the profit per unit sale. It is a useful quantity in carrying out various calculations, and can be used as a measure of production leverage.

The marginal contribution per unit $(C)$ in $\mathrm{kg}$ is given by unit revenue $($ Price, $P$ ) minus unit variable $\operatorname{Cost}(V)$ :

$$
C=P-V
$$

The Contribution Margin Ratio is the percentage of Contribution over Total Revenue, which can be calculated from the unit contribution over unit price or total contribution over Total Revenue:

$$
\frac{C}{P}=\frac{P-V}{P} \times 100=\frac{\text { Total } \text { marginal contribution }}{\text { Total revenue }} \times 100
$$

Marginal contribution in $\mathrm{kg}$ : This gives the $\mathrm{kg}$ required to cover the operational costs and profit equals zero.

Marginal Contribution $(\mathrm{kg})$

$$
=\frac{\text { Marginal Contribution (L.E.) }}{\text { Cost per }(\mathrm{kg}) \text { production (L.E.) }}
$$

\subsubsection{Breakeven analysis}

Breakeven analysis informs producers about the price they need to receive for their product in order to cover all costs of production. It also indicate to the producer, the kilogram of fish, and price for the fish needed to cover the variable, fixed, and total costs of production.

The breakeven cost/price is the price at which the product must be sold in order for profit to be zero. It is also the sales level at which the accruing revenue is exactly equal to the cost of making the output.

$$
\text { Breakeven point }=\frac{\text { Total cost of production }}{\text { Produced quantity }(\mathrm{kg})}
$$

The breakeven per unit yield represents the number of units, or kilograms needed to be sold in order to break even. 


$$
\text { Breakeven point/unit } \mathrm{kg}=\frac{\text { Total cost of production }}{\text { Unit price per } \mathrm{kg}}
$$

\subsubsection{Sensitivity Analysis.}

Sensitivity analysis was conducted to test the effect of some variables on the profitability of the production and to know the areas where an improvement in performance may have a positive impact on the economic performance of the RAS (Losordo \& Westerman, 1994). The simplest form of sensitivity analysis (one-way sensitivity analysis) was employed. This was done by varying one variable by a (+/-) percentage and the impact on the financial performance of the production was examined. The analysis was then repeated for the other variables identified in the operational costs.

The identified cost variables were varied by +/- $10 \%$ since such variations usually occur in commercial productions (De Ionnoet al., 2006).

\subsection{Financial Evaluation.}

An Excel program was developed and used to estimate initial investment, operating costs, and annual returns for the system under study. Production costs and sale price are based on the experiences over the past 14 years at El-Nenaeia fish farm.

\subsubsection{Initial Investment.}

The initial investment (Table 1) includes the total value of a land and effluent pond, building, equipment, construction labor, annual depreciation on building and equipment and interest rate on operating capital.

Table (1): Initial Investment

\begin{tabular}{|l|r|r|}
\hline Initial investment & & \\
\hline \multicolumn{1}{|l|}{ Land } & & L.E. $120,000.00$ \\
\hline Effluent pond & & L.E. $60,000.00$ \\
\hline Equipment & & L.E.1,300,000.00 \\
\hline Building & & L.E. 550,000.00 \\
\hline Construction labor and overhead & & L.E. $100,000.00$ \\
\hline Total initial investment & & L.E.2,130,000.00 \\
\hline Annual depreciation on building & L.E. $171,500.00$ \\
\hline Interest rate on operating capital & & $\mathbf{9 \%}$ \\
\hline \multicolumn{2}{|l|}{ Interest rate on building and equipment } & $\mathbf{1 0 \%}$ \\
\hline
\end{tabular}




\subsubsection{Operating costs and returns.}

Table (2),includes the variable costs, fixed costs, sale price, system parameters, water volume $\left(\mathrm{m}^{3}\right)$, size harvested, survival rate, survival rate and feed cost per $\mathrm{kg}$. It is to be mentioned that, these parameters (tables 1 and 2) are calculated in tables (5 and 6) as set in the program.

Table (2): Operating costs system parameters.

\begin{tabular}{|c|c|c|}
\hline Item & Unit or Description & Value \\
\hline \multicolumn{3}{|l|}{ Variable Costs: } \\
\hline \begin{tabular}{l|l} 
Liquid oxygen \\
\end{tabular} & L.E. per cubic meter & - \\
\hline Energy & L.E. per kW h & 0.20 \\
\hline Bicarbonate & L.E. per kg & 3.00 \\
\hline Fingerlings & L.E. per fingerling & 0.12 \\
\hline Chemicals & L.E. per cycle & 720.00 \\
\hline Maintenance & L.E. per month & $3,800.00$ \\
\hline Labor: management & L.E. per month & $6,000.00$ \\
\hline Labor: transfer \& harvest & L.E. per hour & 50.00 \\
\hline \multicolumn{3}{|l|}{ Fixed Costs: } \\
\hline \begin{tabular}{l|l} 
Liquid oxygen tank rental \\
\end{tabular} & L.E. per month & - \\
\hline Electrical demand charge & L.E. per month & - \\
\hline Building overhead & L.E. per month & 900.00 \\
\hline Average overall sale price & L.E. per kg & 12.00 \\
\hline \multicolumn{3}{|l|}{ System Parameters } \\
\hline Annual production & $\mathrm{kg}$ & 200,000 \\
\hline Average size at harvest & $\mathrm{kg}$ & 0.5 \\
\hline Number of production units & number & 11 \\
\hline Days per production unit & days & 30.5 \\
\hline $\mathrm{kW} h$ per $\mathrm{kg}$ of production & $\mathrm{kWh} \mathrm{kg}^{-3}$ & 3.00 \\
\hline System volts & volts & 230 \\
\hline Transfer/harvest labor & hours per cycle & 64 \\
\hline
\end{tabular}

\section{Economical Results.}

Data in tables 1, 2 and 3 are used to calculate the information were presented in tables 4, 5 and 6. Data in tables 4, 5 and 6 show the operational parameters of the system. 
Table (3): Operating Parameters per Production Unit

\begin{tabular}{|c|c|c|c|c|c|c|c|c|c|c|c|c|}
\hline Item & $\begin{array}{l}\text { Quarantine } \\
\text { Stage }\end{array}$ & $\begin{array}{c}\text { Nursery } \\
\text { Tank } 1\end{array}$ & $\begin{array}{r}\text { Nursery } \\
\text { Tank 2 }\end{array}$ & $\begin{array}{c}\text { Growout } \\
\text { Tank } 1\end{array}$ & $\begin{array}{c}\text { Growout } \\
\text { Tank } 2\end{array}$ & $\begin{array}{c}\text { Growout } \\
\text { Tank } 3\end{array}$ & $\begin{array}{c}\text { Growout } \\
\text { Tank } 4\end{array}$ & $\begin{array}{c}\text { Growout } \\
\text { Tank } 5\end{array}$ & $\begin{array}{c}\text { Growout } \\
\text { Tank } 6\end{array}$ & $\begin{array}{c}\text { Growout } \\
\text { Tank } 7\end{array}$ & $\begin{array}{c}\text { Growout } \\
\text { Tank } 8\end{array}$ & Average \\
\hline Water volume, m3 & 6 & 15 & 15 & 100 & 100 & 100 & 100 & 100 & 100 & 100 & 100 & \\
\hline Size stocked & 1 & 15 & 15 & 60 & 60 & 135 & 135 & 250 & 250 & 385 & 385 & \\
\hline Size harvested & 15 & 60 & 60 & 135 & 135 & 250 & 250 & 385 & 385 & 500 & 500 & \\
\hline Survival rate & 0.95 & 0.99 & 0.99 & 0.99 & 0.99 & 0.99 & 0.99 & 0.99 & 0.99 & 0.99 & 0.99 & 0.90 \\
\hline Feed cost, per kg & 5.50 & 4.50 & 4.50 & 3.80 & 3.80 & 3.80 & 3.80 & 3.80 & 3.80 & 3.80 & 3.80 & \\
\hline Feed conversion & 1.00 & 1.10 & 1.10 & 1.30 & 1.30 & 1.60 & 1.60 & 1.60 & 1.60 & 1.60 & 1.60 & 1.50 \\
\hline
\end{tabular}

Table (4): Inputs per production unit.

\begin{tabular}{|c|c|c|c|c|c|c|c|c|c|c|c|c|c|}
\hline Input Use & $\begin{array}{l}\text { Quarantine } \\
\text { Tank }\end{array}$ & $\begin{array}{c}\text { Nursery } \\
\text { Tank } 1\end{array}$ & $\begin{array}{c}\text { Nursery } \\
\text { Tank 2 }\end{array}$ & $\begin{array}{l}\text { Growout } \\
\text { Tank } 1\end{array}$ & $\begin{array}{l}\text { Growout } \\
\text { Tank 2 }\end{array}$ & $\begin{array}{l}\text { Growout } \\
\text { Tank } 3\end{array}$ & $\begin{array}{l}\text { Growout } \\
\text { Tank } 4\end{array}$ & $\begin{array}{l}\text { Growout } \\
\text { Tank } 5\end{array}$ & $\begin{array}{l}\text { Growout } \\
\text { Tank } 6\end{array}$ & $\begin{array}{l}\text { Growout } \\
\text { Tank } 7\end{array}$ & $\begin{array}{c}\text { Growout } \\
\text { Tank } 8\end{array}$ & $\begin{array}{c}\text { Total per } \\
\text { harvested } \\
\text { cohort }\end{array}$ & $\begin{array}{c}\text { Annual } \\
\text { Total }\end{array}$ \\
\hline Beginning number of & 36,997 & 17,574 & 17,574 & 17,397 & 17,397 & 17,223 & 17,223 & 17,050 & 17,050 & 16,879 & 16,879 & 36,997 & 442,752 \\
\hline Ending number of fish & 35,147 & 17,397 & 17,397 & 17,223 & 17,223 & 17,050 & 17,050 & 16,879 & 16,879 & 16,710 & 16,710 & 35,147 & 420,612 \\
\hline Beginning biomass, kg & 37 & 264 & 264 & 1,044 & 1,044 & 2,325 & 2,325 & 4,263 & 4,263 & 6,498 & 6,498 & 37 & 443 \\
\hline Ending biomass, kg & 527 & 1,044 & 1,044 & 2,325 & 2,325 & 4,263 & 4,263 & 6,498 & 6,498 & 8,355 & 8,355 & 16,710 & 199,972 \\
\hline Maximum standing & 87.87 & 69.59 & 69.59 & 23.25 & 23.25 & 42.63 & 42.63 & 64.98 & 64.98 & 83.55 & 83.55 & --- & --- \\
\hline Feed used, kg & 490 & 858 & 858 & 1,666 & 1,666 & 3,100 & 3,100 & 3,577 & 3,577 & 2,971 & 2,971 & 24,834 & 297,190 \\
\hline kW h used & 1,471 & 2,341 & 2,341 & 3,844 & 3,844 & 5,812 & 5,812 & 6,708 & 6,708 & 5,570 & 5,570 & 50,019 & $\mathbf{5 9 8 , 5 8 8}$ \\
\hline Oxygen used, $\mathbf{m}^{3}$ & 182 & 319 & 319 & 618 & 618 & 1,150 & 1,150 & 1,328 & 1,328 & 1,102 & 1,102 & 2,055 & 24,597 \\
\hline Bicarbonate used, kg & 19 & 33 & 33 & 65 & 65 & 121 & 121 & 140 & 140 & 116 & 116 & 969 & 11,590 \\
\hline
\end{tabular}


Table (5): Costs per production unit (L.E.).

\begin{tabular}{|c|c|c|c|c|c|c|c|c|c|c|c|c|c|}
\hline Input Use & $\begin{array}{l}\text { Quarantine } \\
\text { Tank }\end{array}$ & $\begin{array}{l}\text { Nursery } \\
\text { Tank } 1\end{array}$ & $\begin{array}{l}\text { Nursery } \\
\text { Tank } 2\end{array}$ & $\begin{array}{c}\text { Growout } \\
\text { Tank } 1\end{array}$ & $\begin{array}{l}\text { Growout } \\
\text { Tank } 2\end{array}$ & $\begin{array}{c}\text { Growout } \\
\text { Tank } 3\end{array}$ & $\begin{array}{l}\text { Growout } \\
\text { Tank } 4\end{array}$ & $\begin{array}{l}\text { Growout } \\
\text { Tank } 5\end{array}$ & $\begin{array}{l}\text { Growout } \\
\text { Tank } 6\end{array}$ & $\begin{array}{l}\text { Growout } \\
\text { Tank } 7\end{array}$ & $\begin{array}{l}\text { Growout } \\
\text { Tank } 8\end{array}$ & $\begin{array}{c}\text { Total per } \\
\text { harvested } \\
\text { cohort } \\
\end{array}$ & Annual Total \\
\hline Fingerlings & 4,440 & & & & & & & & & & & 4,440 & 53,130 \\
\hline Feed & 2,696 & 3,862 & 3,862 & 6,330 & 6,330 & 11,779 & 11,779 & 13,594 & 13,594 & 11,288 & 11,288 & 96,403 & $1,153,674$ \\
\hline Energy & 294 & 468 & 468 & 769 & 769 & 1,162 & 1,162 & 1,342 & 1,342 & 1,114 & 1,114 & 10,004 & 119,718 \\
\hline Oxygen & o & $\mathbf{0}$ & $\mathbf{0}$ & $\mathbf{0}$ & 0 & $\mathbf{0}$ & $\mathbf{0}$ & $\mathbf{0}$ & $\mathbf{0}$ & $\mathbf{0}$ & $\mathbf{0}$ & $\mathbf{0}$ & $\mathbf{0}$ \\
\hline Bicarbonate & 57 & 100 & 100 & 195 & 195 & 363 & 363 & 419 & 419 & 348 & 348 & 2,906 & 34,771 \\
\hline $\begin{array}{l}\text { Total of above costs for } \\
\text { this production unit }\end{array}$ & $\mathbf{7 , 4 8 7}$ & 4,431 & $\mathbf{4 , 4 3 1}$ & 7,293 & 7,293 & 13,304 & 13,304 & 15,354 & 15,354 & 12,750 & 12,750 & 113,752 & $1,361,293$ \\
\hline $\begin{array}{l}\text { Cumulative cost for } \\
\text { cycle }\end{array}$ & 7,487 & 8,174 & 8,174 & 15,467 & 15,467 & 15,467 & 15,467 & 15,467 & 15,467 & 15,467 & 15,467 & 147,575 & $1,766,067$ \\
\hline
\end{tabular}


Table (6): Annual costs and returns to system in full production

\begin{tabular}{|c|c|c|c|c|c|c|c|}
\hline Items & Unit & cost/unit & $\begin{array}{c}\text { quantity/ harvest } \\
\text { cycle }\end{array}$ & $\begin{array}{c}\text { L.E. } \\
\text { /harvest }\end{array}$ & L.E. /year & $\begin{array}{c}\text { L.E per } \\
\mathrm{kg} \text { of fish }\end{array}$ & $\begin{array}{l}\% \text { of } \\
\text { total }\end{array}$ \\
\hline \multicolumn{8}{|l|}{ Variable Cost } \\
\hline fingerlings & each & 0.12 & $36,997.07$ & $4,439.65$ & $53,130.23$ & 0.27 & $2.85 \%$ \\
\hline feed & kg & 3.88 & $24,833.69$ & $96,402.92$ & $1,153,674.24$ & 5.77 & $61.83 \%$ \\
\hline energy & kWh & 0.20 & $50,019.01$ & $10,003.80$ & $119,717.63$ & 0.60 & $6.42 \%$ \\
\hline oxygen & Cubic meter & $\mathbf{0 . 0 0}$ & 92.17 & 0.00 & 0.00 & 0.00 & $0.00 \%$ \\
\hline bicarbonate & kg & $\mathbf{3 . 0 0}$ & 968.51 & $2,905.54$ & $34,771.24$ & 0.17 & $1.86 \%$ \\
\hline chemicals & L.E. /harvest cycle & 721.97 & 1.00 & 721.97 & $\mathbf{8 , 6 4 0 . 0 0}$ & 0.04 & $0.46 \%$ \\
\hline maintenance & L.E. /harvest cycle & $3,810.41$ & 1.00 & $3,810.41$ & $45,600.00$ & 0.23 & $2.44 \%$ \\
\hline labor: management & L.E. /harvest cycle & $6,016.44$ & 1.00 & $6,016.44$ & $72,000.00$ & 0.36 & $\mathbf{3 . 8 6 \%}$ \\
\hline labor: transfer \& harvest & L.E. /harvest cycle & $\mathbf{5 0 . 0 0}$ & 64.00 & $3,200.00$ & $38,295.08$ & 0.19 & $2.05 \%$ \\
\hline interest on variable costs & L.E. & 0.09 & $65,970.19$ & $5,457.45$ & $65,310.49$ & $\mathbf{0 . 3 3}$ & $3.50 \%$ \\
\hline Subtotal, Variable Cost & & & & $132,958.18$ & $1,591,138.90$ & 7.96 & $\mathbf{8 5 . 2 7 \%}$ \\
\hline \multicolumn{8}{|l|}{$\frac{1}{\text { Fixed Cost }}$} \\
\hline oxygen tank rental & L.E. & & & $\mathbf{0 . 0 0}$ & 0.00 & $\mathbf{0 . 0 0}$ & $0.00 \%$ \\
\hline electrical demand charge & L.E. & & & 0.00 & 0.00 & 0.00 & $0.00 \%$ \\
\hline building overhead & L.E. & & & 902.47 & $10,800.00$ & 0.05 & $0.58 \%$ \\
\hline interest on bldg. \& equip. & L.E. & & & $7,729.45$ & $92,500.00$ & 0.46 & $4.96 \%$ \\
\hline depreciation on bldg. \& equip. & L.E. & & & $14,330.82$ & $171,500.00$ & 0.86 & $9.19 \%$ \\
\hline Subtotal, Fixed Cost & & & & $22,962.74$ & $274,800.00$ & 1.37 & $14.73 \%$ \\
\hline Total Costs & & & & $155,920.92$ & $1,865,938.90$ & 9.33 & $100 \%$ \\
\hline Returns above Variable Costs & & & & $67,561.82$ & $808,526.67$ & 4.04 & \\
\hline Returns above Total Costs & & & & $44,599.08$ & $533,726.67$ & 2.67 & \\
\hline \multicolumn{2}{|c|}{ Breakeven point price L.E./kg ( above Variable Costs) } & & & & & 7.96 & \\
\hline \multicolumn{2}{|c|}{ Breakeven point price L.E./kg ( above Total Costs) } & & & & & 9.33 & \\
\hline \multicolumn{2}{|l|}{ Breakeven point unit $\mathrm{kg} / \mathrm{year}$} & & & & & 155494.91 & \\
\hline
\end{tabular}


3.1 Total costs, returns and breakeven point.

From table (6) the total cost per kg produced, per cycle and per year were 9.33, 155,921 and 1,865,939 L.E., respectively. Returns above variable costs were 4.04, 67,562 and 808,527 L.E. and above total costs were 2.67, 44,599 and 533,727 L.E. for the same previous order, respectively. Breakeven point price over variable and fixed cost and breakeven point unit were 7.96 L.E kg-1, 9.33 L.E. kg ${ }^{-1}$ and 155,495 kgyear $^{-1}$, respectively. These results show the economic feasibility of the system.

\subsection{Outcomes/Incomes.}

Table (7) shows the percentage of outcome to income, which was 1.24.

Table (7) Percentage of outcomes to incomes.

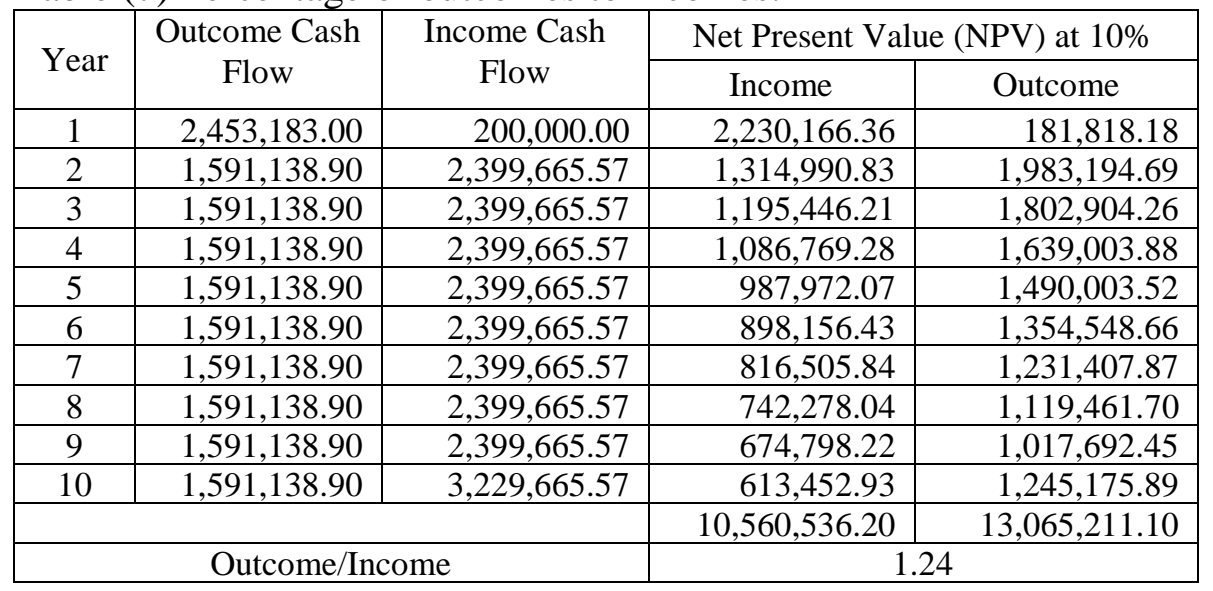

3.3 Internal Return Rate (IRR).

Table (8) shows the internal return rate (IRR), which was $34 \%$.

3.4 Payback Period.

Table (9) shows that the payback period is 3.79 years.

3.5 Sensitivity Analysis

A variation of $+/-10 \%$ was used to analyze the capital variables and revenues, respectively. Table (10) shows the effect of increasing in the outcome cash flow by $+10 \%$ on internal return rate (IRR), which was $23 \%$. Table (11) shows the effect of decreasing income cash flow by $10 \%$ on internal return rate (IRR), which was $22 \%$. Table (12) shows the 
effect of increasing outcome cash flow and decreasing income cash flow about $\pm 10 \%$, which was $11 \%$.

Table (8) Internal Return Rate (IRR).

\begin{tabular}{|c|r|r|r|}
\hline Year & Outcome Cash Flow & Income Cash Flow & Net Cash Flow \\
\hline 1 & $2,453,183.00$ & $200,000.00$ & $-2,253,183.00$ \\
\hline 2 & $1,591,138.90$ & $2,399,665.57$ & $808,526.67$ \\
\hline 3 & $1,591,138.90$ & $2,399,665.57$ & $808,526.67$ \\
\hline 4 & $1,591,138.90$ & $2,399,665.57$ & $808,526.67$ \\
\hline 5 & $1,591,138.90$ & $2,399,665.57$ & $808,526.67$ \\
\hline 6 & $1,591,138.90$ & $2,399,665.57$ & $808,526.67$ \\
\hline 7 & $1,591,138.90$ & $2,399,665.57$ & $808,526.67$ \\
\hline 8 & $1,591,138.90$ & $2,399,665.57$ & $808,526.67$ \\
\hline 9 & $1,591,138.90$ & $2,399,665.57$ & $808,526.67$ \\
\hline 10 & $1,591,138.90$ & $3,229,665.57$ & $1,638,526.67$ \\
\hline \multicolumn{2}{|r}{} & \multicolumn{2}{|c}{0.34} \\
\hline
\end{tabular}

Table (9) Payback Period.

\begin{tabular}{|c|c|c|}
\hline Year & Yearly Revenue & $\begin{array}{l}\text { Accumulation } \\
\text { Revenue }\end{array}$ \\
\hline 1 & $-2,253,183$ & $(2 \cdot 253,183)$ \\
\hline 2 & 808,527 & $(1 ، 444,656)$ \\
\hline 3 & 808,527 & $(6636,130)$ \\
\hline 4 & 808,527 & ،172,397 \\
\hline 5 & 808,527 & ،980,924 \\
\hline 6 & 808,527 & $1.789,450$ \\
\hline 7 & 808,527 & $2.597,977$ \\
\hline 8 & 808,527 & $3 ، 406,504$ \\
\hline 9 & 808,527 & $4 \cdot 215,030$ \\
\hline 10 & $1,638,527$ & $5.853,557$ \\
\hline
\end{tabular}

Table (10):Effect of increasing in the outcome cash flow by $+10 \%$ on internal return rate (IRR).

\begin{tabular}{|c|r|r|r|}
\hline Year & Outcome Cash Flow+10\% & Income Cash Flow & \multicolumn{1}{c|}{ Net Cash Flow } \\
\hline 1 & $2,698,501.30$ & $200,000.00$ & $-2,498,501.30$ \\
\hline 2 & $1,750,252.79$ & $2,399,665.57$ & $649,412.78$ \\
\hline 3 & $1,750,252.79$ & $2,399,665.57$ & $649,412.78$ \\
\hline 4 & $1,750,252.79$ & $2,399,665.57$ & $649,412.78$ \\
\hline 5 & $1,750,252.79$ & $2,399,665.57$ & $649,412.78$ \\
\hline 6 & $1,750,252.79$ & $2,399,665.57$ & $649,412.78$ \\
\hline 7 & $1,750,252.79$ & $2,399,665.57$ & $649,412.78$ \\
\hline 8 & $1,750,252.79$ & $2,399,665.57$ & $649,412.78$ \\
\hline 9 & $1,750,252.79$ & $2,399,665.57$ & $649,412.78$ \\
\hline 10 & $1,750,252.79$ & $3,229,665.57$ & $1,479,412.78$ \\
\hline & IRR & 0.23 \\
\hline
\end{tabular}


Table (11):Effect of decreasing income cash flow by $-10 \%$ on internal return rate (IRR).

\begin{tabular}{|c|r|c|c|}
\hline Year & Outcome Cash & Income Cash Flow-10\% & Net Cash \\
\hline 1 & $2,453,183.00$ & $180,000.00$ & $-2,273,183.00$ \\
\hline 2 & $1,591,138.90$ & $2,159,699.02$ & $568,560.12$ \\
\hline 3 & $1,591,138.90$ & $2,159,699.02$ & $568,560.12$ \\
\hline 4 & $1,591,138.90$ & $2,159,699.02$ & $568,560.12$ \\
\hline 5 & $1,591,138.90$ & $2,159,699.02$ & $568,560.12$ \\
\hline 6 & $1,591,138.90$ & $2,159,699.02$ & $568,560.12$ \\
\hline 7 & $1,591,138.90$ & $2,159,699.02$ & $568,560.12$ \\
\hline 8 & $1,591,138.90$ & $2,159,699.02$ & $568,560.12$ \\
\hline 9 & $1,591,138.90$ & $2,159,699.02$ & $568,560.12$ \\
\hline 10 & $1,591,138.90$ & $2,906,699.02$ & $1,315,560.12$ \\
\hline \multicolumn{4}{|l|}{0.22} \\
\hline
\end{tabular}

Table (12):Effect of increasing outcome cash flow and decreasing income cash flow about $\pm 10 \%$ on internal return rate (IRR).

\begin{tabular}{|c|c|c|c|}
\hline Year & Outcome Cash Flow+10\% & Income Cash Flow-10\% & Net Cash Flow \\
\hline 1 & $2,698,501.30$ & $180,000.00$ & $-2,518,501.30$ \\
\hline 2 & $1,750,252.79$ & $2,159,699.02$ & $409,446.23$ \\
\hline 3 & $1,750,252.79$ & $2,159,699.02$ & $409,446.23$ \\
\hline 4 & $1,750,252.79$ & $2,159,699.02$ & $409,446.23$ \\
\hline 5 & $1,750,252.79$ & $2,159,699.02$ & $409,446.23$ \\
\hline 6 & $1,750,252.79$ & $2,159,699.02$ & $409,446.23$ \\
\hline 7 & $1,750,252.79$ & $2,159,699.02$ & $409,446.23$ \\
\hline 8 & $1,750,252.79$ & $2,159,699.02$ & $409,446.23$ \\
\hline 9 & $1,750,252.79$ & $2,159,699.02$ & $409,446.23$ \\
\hline 10 & $1,750,252.79$ & $2,906,699.02$ & $1,156,446.23$ \\
\hline \multicolumn{3}{|c|}{0.11} \\
\hline
\end{tabular}

\section{CONCLUSION}

According to the obtained results, it could be concluded that to produce one $\mathrm{kg}$ of fish, it would cost 9.33 LE, while will profit 2.67 LE which represents $28.6 \%$. The results should that, above variable and total cost were 4.04 LE and 2.67 LE, respectively. Incomes/outcomes was 1.24, IRR recorded 0.34 . The payback period was 3.79 years. The results showed that, the operational cost involving the system production was suited and economically viable. 


\section{REFERENCES:}

Alceste, C.C. and Jory, D.E. (2002). World tilapia farming. available at:http://www.aquaculturemag./com/siteenglish/printed/buyers/eb.ti lapia.html.

Ali, S.A., Z.A. El-Haddad and A. Ghareib. (2006). Design and Management of El-Nenaeia Fish Farm: as a Recirculating Aquaculture System. Misr Society of Agr. Eng., April (2006): Vol. 23(2):

Bjørndal, T. (1987). Bio economic analyse, pp. 92-131. In T. Bjørndal (ed.) Aquaculture economics, pages 173. J. W. Cappelens, J.W. Publisher AS, Oslo, Norway.

De Ionno, P.N., Wines, G.L., Jones, P.L., Collins, R.O. (2006). A bio economic evaluation of a commercial scale recirculating finfish grow out system: An Australian perspective. Published in Aquaculture journal volume 259, - page 315-327.

FAO. (2009). Fisheries global information system. In FAO, accessed on World Wide Web: http://www.fao.org/fishery/statistics/en.

FAO. (2010). Fisheries global information system. In FAO, accessed on World Wide Web: http://www.fao.org/fishery/statistics/en.

FAO GLOBEFISH (2011a) Tilapia Market Report. URL: http://www.globefish.org/tilapiafebruary- 2012.html.

Helfrich, L.A., and Libey, G. 1990. Fish Farming in Recirculating Aquaculture Systems. Department of Fisheries and Wildlife Sciences, Virginia Tech, Virginia. Accessed on the URL: http://www aces.edu /dept/fisheries/aquaculture/documents/recirculatingVT.pdf.

Hoff, K. G. (1998). Cost performance volume analysis, p. 379-403. In K. G. Hoff (ed.) Basic Business Management, 493 p. TanoAschehoug, AiTEnger AS, Otta, Norway.

Jahncke, M.L., Schwarz, M.H. (2000). Application of hazard analysis and critical control point (HACCP) Principles as a risk management approach for re-circulating aquaculture systems 
(RAS). Proceedings of the Third International Symposium on Recirculating Aquaculture Systems, Roanoke, Virginia, July.

Kazmierczak Jr., R.F., Caffey, R.H. (1995). Management ability and the economics of recirculating aquaculture production systems. Published in Marine Resource Economics volume 10, 187-209. URL: http://ageconsearch.umn.edu/bitstream/49031.

Losordo, T. M., and P. Westerman., (1994). An Analysis of Biological, Economic, and Engineering Factors Affecting the Cost of Fish Production in Recirculating Aquaculture Systems. Pages 1-9 In Workshop on the Design of High-Density Recirculating Aquaculture Systems. Louisiana Sea Grant College Program, Louisiana State University, Baton Rouge.

Martins, C.I.M., Eding, E.H., Verdegem, M.C.J., Heinsbroek, L.T.N., Schneider, O., Blancheton, J.P., Rogue d'Orbcastel E., and Verreth J.A.J. (2010) : New developments in recirculating aquaculture systems in Europe: A perspective on environmental sustainability. Aquacultural Engineering, November 2010, Volume 43, Issue 3, Pages 83- 93.

Martins, C.I.M., Eding, E.H., Schneider, O., Rasmussen, R., Olesen, B., Plesner, L., Verreth, J.A.J. (2005). Recirculation Aquaculture Systems in Europe. CONSENSUS. Oostende, Belgium, Consensus working Group, European Aquaculture Society: 31.

Masser, M.P., Rakocy, J. and Losordo, T.M. (1999). Recirculating Aquaculture Tank Production Systems: Management of Recirculating Systems. SRAC Publication No. 452, Page 12. In Martins, C.I.M., Eding, E.H., Verdegem, M.C.J., Heinsbroek, L.T.N., Schneider, O., Blancheton, J.P., Rogue d'Orbcastel E., and Verreth J.A.J. (2010): New developments in recirculating aquaculture systems in Europe: A perspective on environmental sustainability. Aquacultural Engineering, November 2010, Volume 43, Issue 3.

Piedrahita, R.H. (2003). Reducing the Potential Environmental Impact of Tank Aquaculture Effluents through Intensification and 
Recirculation. Aquaculture. 226, pp 35-44. In In Martins, C.I.M., Eding, E.H., Verdegem, M.C.J., Heinsbroek, L.T.N., Schneider, O., Blancheton, J.P., Rogue d'Orbcastel E., and Verreth J.A.J. (2010): New developments in recirculating aquaculture systems in Europe: A perspective on environmental sustainability. Aquacultural Engineering, November 2010, Volume 43, Issue 3.

Rawlinson, P. and Forster, A. (2000). The Economics of Recirculation Aquaculture. Fisheries Victoria. Department of Natural Resources and Environment. Australia. URL: http://oregonstate.edu/dept /IIFET/2000/papers/rawlinson.pdf.

Rawlinson, P. (2002). The economic efficiencies of partial and intensive recirculation aquaculture systems for Murray cod. In: Ingram, B.A. (Ed.), Murray Cod Aquaculture: Now and Into the Future. Victorian Institute of Animal Science, Attwood, Victoria, Australia, page 17-18.

Schneider, O., Blancheton, J. P., Varadi, L., Eding, E. H., and Verreth, J. A. J. (2006). Cost price and Production Strategies in European Recirculation Systems. Linking Tradition \& Technology Highest Quality for the Consumer, Firenze, Italy. World Aquaculture Society Conference proceedings.

Schneider, O., Schram, E., Poelman, M., Rothuis, A., van Duijn, A., van der Mheen, H.(2010). Practices in managing finfish aquaculture using ras technologies, the dutch example. OECD workshop on Advancing the Aquaculture Agenda, Paris, France, OECD. In Martins, C.I.M., Eding, E.H., Verdegem, M.C.J., Heinsbroek, L.T.N., Schneider, O., Blancheton, J.P., Rogue d'Orbcastel E., and Verreth J.A.J. (2010): New developments in recirculating aquaculture systems in Europe: A perspective on environmental sustainability. Aquacultural Engineering, November 2010, Volume 43, Issue 3.

Smith, S.A. (1996). HACCP Program for Disease and Therapeutics for Intensive Culture of Food Fish. In. Libey, G.S. and Timmons, M.B., eds. Successes and Failures in Commercial Recirculating 
Aquaculture. In: Proceedings of an International Workshop, Roanoke, Virginia, July 19-21, 1996 pp. 344-345.

Summerfelt, S.T., Sharrer, M.J., Tsukuda, S.M., Gearheart, M. (2009). Process Requirements for Achieving full-flow Disinfection of Recirculating water using ozonation and UV irradiation Aquaculture. Eng. 40, 17-27. In Martins, C.I.M., Eding, E.H., Verdegem, M.C.J., Heinsbroek, L.T.N., Schneider, O., Blancheton, J.P., Rogue d'Orbcastel E., and Verreth J.A.J. (2010): New Developments in Recirculating Aquaculture Systems in Europe: A Perspective on Environmental Sustainability. Aquacultural Engineering, November 2010, Volume 43, Issue 3.

Timmons, M.B, Ebeling, J.M., Wheaton, F.W, Summerfelt, S.T., Vinci, B.J. (2001). Recirculating Aquaculture Systems. NRAC Publication no. 01-002, Cayuga Aqua Ventures, Ithaca, NY, Page650.

Verdegem, M. C. J., Bosma, R. H., Verreth, J. A. J. (2006). Reducing water use for animal production through aquaculture. International journal on Water Resource Development. 22, 101-113. In Martins, C.I.M., Eding, E.H., Verdegem, M.C.J., Heinsbroek, L.T.N., Schneider, O., Blancheton, J.P., Rogue d'Orbcastel E., and Verreth J.A.J. (2010): New developments in recirculating aquaculture systems in Europe: A perspective on environmental sustainability. Aquacultural Engineering, November 2010, Volume 43, Issue 3, Pages 83-93.

Zohar, Y., Tal, Y., Schreier, H. J., Steven, C., Stubblefield, J. and Place, A. (2005). Commercially feasible urban recirculate aquaculture: Addressing the marine sector. In Martins, C.I.M., Eding, E.H., Verdegem, M.C.J., Heinsbroek, L.T.N., Schneider, O., Blancheton, J.P., Rogue d'Orbcastel E., and Verreth J.A.J. (2010): New developments in recirculating aquaculture systems in Europe: A perspective on environmental sustainability. Aquacultural Engineering, November 2010, Volume 43, Issue 3, Pages 83-93. 


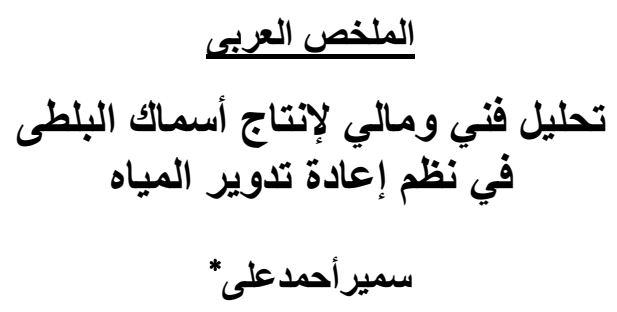

تحتل مصر المرتبة الثانية بعد الصين فى إنتاج أسماك البلطى فى العالم، إلا أن معظم هذا الإنتاج

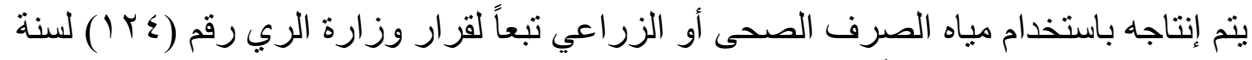

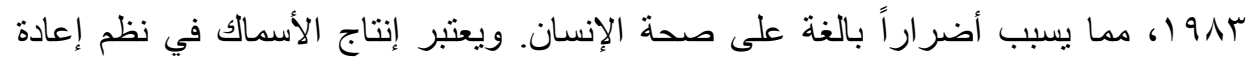

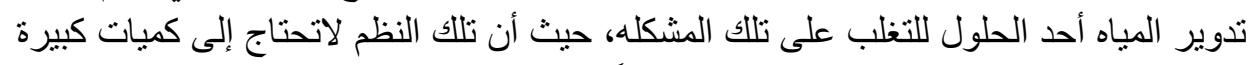

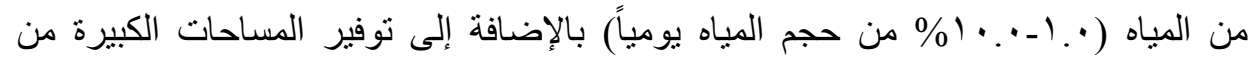
الأر اضى، حيث أن تلك النظم تعتمد على التكثيف (معظمة إنتاجية الوحدة).

لذا كان من الضرورى دراسة تلك النظم فنباً ومالياً للوقوف على مدى إلى إمكانية تطبيقها إقتصادياً

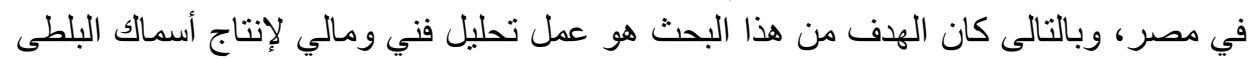

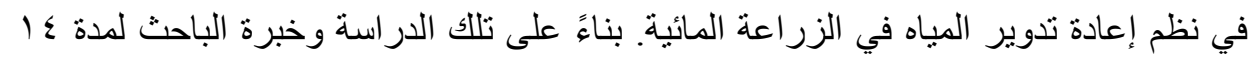

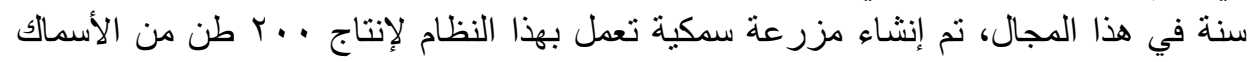

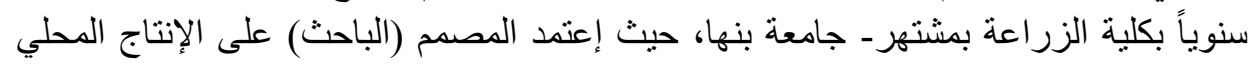
كلما توفر ذللك لتقليل التكاليف الإستثمارية.

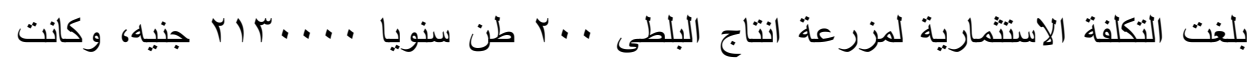

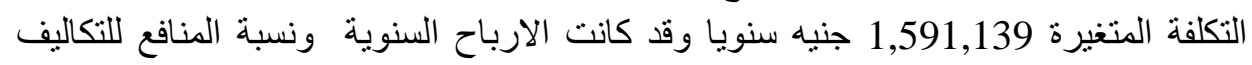

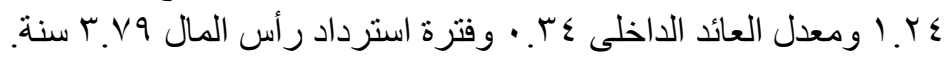

وقد أجرى إختبار الحساسية وأسفرت عن النتائج التالية:

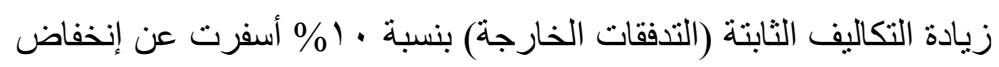

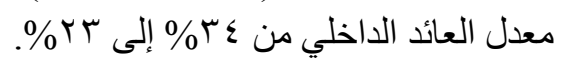

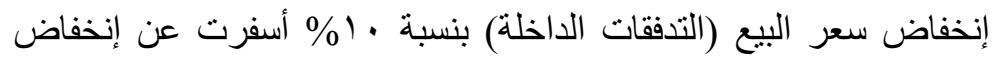

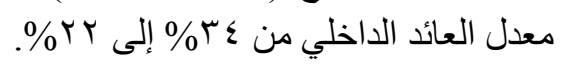

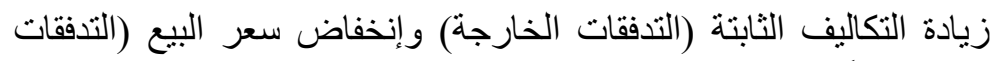

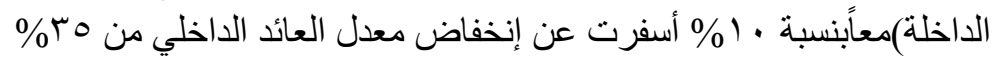

$$
\text { إلى 1) }
$$

ومن هنا تأتى اهمية الدراسة فى القاء الضوء على مدى جدوى الاستثمار فى هذه المشاريع.

* أستاذ الهندسة الزراعية المساعد ـ كلية الزراعةـ جامعة بنها 